\title{
Sprawl in Europe and America
}

\author{
MICHAEL LEWYN*
}

\section{TABLE OF CONTENTS}

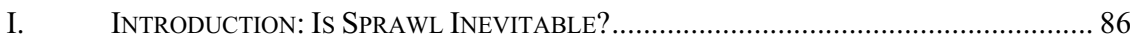

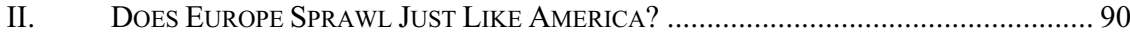

A. $\quad$ The Storytelling Behind the Inevitability Theory ....................................... 90

B. Flaw One in the Story: Europe Does Not Sprawl

Like the United States .................................................................................... 91

C. Flaw Two in the Story: Europe Is Not Turning

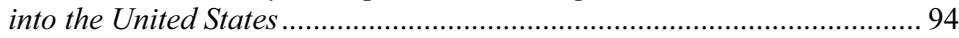

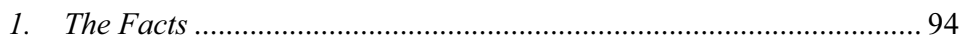

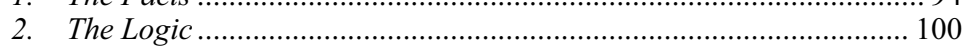

III. Even In Europe, Some Government Policies Create SpRAWL .................... 101

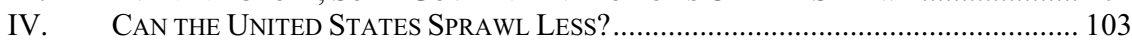

A. Less Government, Less Sprawl Too ................................................... 104

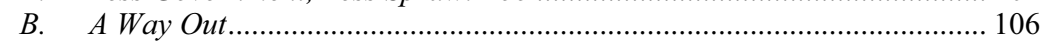

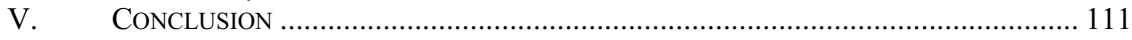

* Associate Professor, Florida Coastal School of Law. B.A., Wesleyan University; J.D., University of Pennsylvania. I would like to thank Eliza Hall, James Kushner, Christopher Roederer, and my volunteer research assistant Zahava Essig for their helpful comments. Any errors of fact or logic are, of course, mine rather than theirs. 


\section{INTRODUCTION: IS SPRAWL INEVITABLE?}

The metropolitan United States is dominated by "sprawl"-automobileoriented development, usually located in suburbs. ${ }^{1}$ "Many older American cities have lost population to their suburbs, ${ }^{2}$ and residents of those suburbs are highly dependent on automobiles. ${ }^{3}$ In many American neighborhoods and suburbs, population densities are so low that few people live within walking distance of public transit, shops, or jobs, ${ }^{4}$ buildings are surrounded by parking lots that are unpleasant destinations for pedestrians, ${ }^{5}$ and streets are so long and wide that pedestrians cannot comfortably cross them. ${ }^{6}$

1. See Oliver Gillham, The Limitless City: A Primer on the Urban Sprawl DEBATE 4 (2002) (listing a variety of definitions of sprawl, most of which emphasize development far from regional cores as well as the automobile-oriented nature of sprawl development). In $1950,41 \%$ of the metropolitan population lived in suburbs; in 2000, $62 \%$ lived in suburbs. Id. at 18; see infra note 3 (stating that suburbanites are heavily dependent on automobiles).

2. GILlHAM, supra note 1, at 140-41 (explaining that cities generally gained population by annexing suburbs).

3. See People v. Coutard, 454 N.Y.S.2d 639, 642 (N.Y. Dist. Ct. 1982) ("In a suburban county ... the use of an automobile by most of its citizens is often as necessary as placing bread upon their tables."); Roberta F. Mann, On the Road Again: How Tax Policy Drives Transportation Choice, 24 VA. TAX REV. 587, 607 (2005) (noting that most suburban jobs cannot be reached through public transit (citing Angela Glover Blackwell, Promoting Equitable Development, 34 InD. L. REV. 1273, 1279 (2001))).

4. The typical American house consumes about 8750 square feet of land, or about one-fifth of an acre. See RoBert BRUEGMANN, SPRAWL: A COMPACT HistORY 68 (2005); Arthur Allen Leff, The Leff Dictionary of Law: A Fragment, 94 YALE L.J. 1855, 1905 (1985) (defining an acre as containing 43,560 square feet). Thus, the average American residential neighborhood has five houses per acre - not enough density to support significant public transit ridership. See Robert H. Freilich, The Land-Use Implications of Transit-Oriented Development: Controlling the Demand Side of Transportation Congestion and Urban Sprawl, 30 URB. LAW. 547, 552 \& n.18 (1998) (noting that because commuters will generally not walk more than a quarter of a mile to a transit stop or station, "residential densities of at least 7-15 dwelling units per acre are needed in order to encourage the utilization of public transit").

5. Most American local governments require businesses, apartment complexes, and other landowners to provide off-street parking for their customers. See DonALD C. Shoup, The High Cost of Free PARKing 22-24 (2005). These parking lots are usually in front of buildings for two reasons. First, underground parking is more expensive for landowners to build than aboveground parking lots. See Nancy Sarnoff \& David Kaplan, Real Estate: This Luxury Is for Display Purposes Only; Full-Scale Models Aim to Sell Condos Before They've Even Been Built, Hous. CHron., Aug. 26, 2007, at C3, available at $\mathrm{http}: / /$ www.chron.com/CDA/archives/archive.mpl?id=2007_4411742 (referencing developer's assertion that underground parking makes mixed-use developments more costly). Second, government regulations typically require that buildings be set back from the street. See William B. Stoebuck \& Dale A. Whitman, The Law of Property 598 (3d ed. 2000 ) (noting that most zoning ordinances use setbacks to control density). So as long as developers have to place something between the street and a building, a parking lot is a logical option. These parking lots are unpleasant places for pedestrians because a journey 
Environmentalists assert that sprawl increases global warming and air pollution by increasing the amount of driving, and that the spread of suburbia into the countryside reduces wildlife habitat and farmland. ${ }^{7}$ Other commentators complain that automobile-dependent development: (1) immobilizes Americans who are either incapable of driving or paying automobile-related expenses; ${ }^{8}(2)$ intensifies traffic congestion by amplifying the number of cars on the road; ${ }^{9}$ and (3) makes Americans more obese by depriving them of opportunities to walk. ${ }^{10}$ Sprawl critics also assert that sprawl is in large part the result of pro-sprawl public policies such

through a parking lot takes more time than a journey from a sidewalk to a shop directly adjacent to that sidewalk. See Renee Elder, Green Hills Tries to Catch Its Breath: Advisory Group Working to Make Retail Area More Livable Before It Chokes on Its Own Success, TENNESSEAN, June 4, 1999, at E1 (quoting local planner as stating that "[a]nytime your buildings are set back behind parking lots, they're more difficult for pedestrians to reach"); Amy Sutherland, Push for 'New Urbanism': Most Neighborhoods and Downtowns Seem to Discourage Spontaneous Human Interaction, Portland Press Herald, Jan. 1, 1998, at A1, available at 1998 WLNR 5763795 (pointing out that where buildings are set back from the street and pedestrians have to walk through a parking lot to reach buildings, the landscape seems "vast" and "unfriendly looking").

6. See Sally Cragin, L.A. Shines with Many Alternatives to Disneyland, Boston HerAld, Aug. 25, 1996, at 67, available at 1996 WLNR 262869 (stating that many major surface streets in Los Angeles are six to eight lanes wide); Jim Schaefer, Walking the Whole Way Up Woodward: The Avenue from Detroit to Pontiac Is Paved with 26 Miles of History - and It's Celebrating Its 200th Anniversary, DETROIT FREE PRESS, Aug. 17, 2007, at A1, available at 2007 WLNR 15984999 (explaining the transformation of Woodward Avenue, a major street in Detroit, that is now ten lanes wide); Susan Warner, Trials of Travel on City Avenue, PHILA. INQUIRER, Feb. 26, 1987, at M5, available at 1987 WLNR 533119 (noting that Philadelphia's City Avenue is eight lanes wide); see infra notes 135-43 and accompanying text explaining why wide streets discourage walking.

7. See Gillham, supra note 1, at 75-76 (describing pollution, habitat loss, and farmland loss caused by sprawl); Eliza Hall, Note, Divide and Sprawl, Decline and Fall: A Comparative Critique of Euclidean Zoning, 68 U. PITT. L. REV. 915, 928 (2007) ("In addition to obliterating farmland and wilderness, sprawl increases air pollution and aggravates global warming by making people dependent on cars: '[t]ransportation is responsible for one-third of all greenhouse gases generated by Americans . . . ."” (footnote omitted)).

8. See Andres Duany et al., Suburban Nation: The Rise of Sprawl and the DECLINE OF THE AMERICAN DREAM 116, 123 (2000) (explaining that an inability to walk to most activities limits the mobility of children and the elderly); GILLHAM, supra note 1, at 137 (describing difficulties facing nondriving commuters); Angela Glover Blackwell, Promoting Equitable Development, 34 InD. L REV. 1273, 1279 (2001) (reporting that most welfare recipients lack cars); Susan Williams, Drive Smarter Challenge Aimed at Gas Savings, Charleston GAZETTE, May 23, 2008, at A8, available at 2008 WLNR 9813057 (describing impact of rising fuel prices upon working, driving poor).

9. See Gillham, supra note 1 , at 93.

10. Id. at 76 . 
as zoning and street design regulations that favor the status quo. ${ }^{11}$ And by favoring highways over public transit, government transportation policies encourage people to move to the automobile-dependent suburbs created by those regulations. ${ }^{12}$

In response, defenders of the status quo assert that sprawl is an inevitable result of consumer preferences in an affluent, open society. ${ }^{13}$ For example, Robert Bruegmann, author of a recent book on sprawl, claims that affluent households have sought to escape cities since the days of the Roman Empire. ${ }^{14}$ Bruegmann also asserts that affluence has enabled middle class Europeans to do the same. ${ }^{15}$ He accordingly concludes that sprawl is a "predictable result of increasing wealth" and that any attempts to restrict sprawl will be ineffective. ${ }^{16}$ In other words, Bruegmann and other pro-sprawl commentators rely on a kind of "Inevitability Theory" of sprawl: Sprawl is inevitable and thus government cannot and should not try to resist this trend. ${ }^{17}$

11. See discussion infra Part IV.B.

12. See GillhaM, supra note 1, at 126-30.

13. See infra notes 14-17 and accompanying text; Nicole Stelle Garnett, Save the Cities, Stop the Suburbs?, 116 YALE L.J. 598, 603 (2006) (reviewing BRUEGMANN, supra note 4 \& Joel KotKin, THe City: A Global History (2005)) ("[S]prawl is . . . a natural result of affluence that benefits even those of the most modest means."); Robert I. McMurry, The Intelligence of Growth: If the Future is "Smart Growth," What Have I Been Doing for the Last 30 Years?, 1999 LAND UsE InST.: Plan. Reg. Litig. EMINENT DOMAIN \& COMPENSATION 125. Fred Seagle, a Cooper Union professor, describes sprawl as "the price we pay for creating something new on the face of the earth; the first mass upper-middle class." Id. at 131. Furthermore, J. Ducox, an Illinois public policy analyst, characterizes urban sprawl as "simply reflecting the increasing affluence of the country in which people get 'bigger houses, more cars, more space and that kind of thing." Id. at 131-32; cf. Benjamin Krass, Comment, Combating Urban Sprawl in Massachusetts: Reforming the Zoning Act Through Legal Challenges, 30 B.C. ENVTL. AFF. L. REV. 605, 607 (2003) (criticizing urban sprawl, but nevertheless describing sprawl as "the demand of an increasingly affluent population to live in the spacious countryside" (citing Robert H. FreILICH, FROM SPRAWL TO SMART GrowTH: SUCCESSFul LEgAL, PlanNING, AND ENVIRONMENTAL SYSTEMS 2 (1999))).

14. See BRUEGMANN, supra note 4 , at 23-24.

15. Id. at 73-78 (describing suburbanization in Europe).

16. Id. at 10-11;201-02 (citing European sprawl as example).

17. See, e.g., BruEgmanN, supra note 4, at 11 ("[R]emedies [for sprawl] have been ineffective .....”); RANDAL O'TOOLE, THE BEST-LAID Plans 109 (2007) (asserting that because Europeans are moving to suburbs and driving more often, "European cities are looking more American every year"); Kenny Seale, The Effect of the Wild and Scenic Rivers Act on Proposed Bridge Construction: Sierra Club North Star Chapter v. Pena, 7 Wis. ENVTL. L.J. 225, 259 (2000) (stating that Minnesota and Wisconsin believe that "urban sprawl and economic development are inevitable" and accordingly favor controversial bridge widening); Vincent Carroll, A New Look at Sprawl, ROCKY MTN. NEWS, July 31, 2007 , at 27 (maintaining that "[s]prawl is also inevitable . . . in any society whose affluence and population are growing"); PETER GORDON \& HARRY W. RICHARDSON, POLICY ANALYSIS No. 365: CRITIQUING SPRAWL's CRITICS 5 (2000), http://www.cato.org/ pubs/pas/pa365.pdf (suggesting that sprawl is likely even where public policy favors more compact development because "widespread automobile ownership and suburban 
The Inevitability Theory turns on a comparative analysis of the United States and other affluent societies. If other affluent societies fail to adopt pro-sprawl public policies and yet are as sprawling and automobile dependent as the United States, then sprawl, whatever its negative effects, may be an irresistible result of affluence and consumer preferences. However, if other affluent societies are, in fact, either less sprawling than the United States, or suburbanizing like the United States because their governments have adopted public policies that favor sprawl, then the Inevitability Theory collapses.

This Article compares Western Europe to the United States and finds that: (1) Europe is far less automobile dependent than the United States; and (2) to the limited extent that Europe has sprawled, European governments' pro-sprawl public policies may be partially to blame. It logically follows that the Inevitability Theory is simply wrong - sprawl can be, and in fact has been, limited in the affluent societies of Western Europe. ${ }^{18}$

Part II of this Article shows that European nations in fact sprawl less than the United States in a variety of ways. Europeans walk, bike, and use public transit far more than Americans. Transit ridership is rising, and European urban cores are reasonably healthy. Part III shows that like the United States, European nations have promoted sprawl by building highways. Therefore, to the extent that European cities have sprawled into the countryside, such sprawl may be the result of pro-sprawl government policies rather than an inevitable result of affluence. Part IV rejects the argument that sprawl can only be limited through statist policies, which would be politically impossible in the United States. ${ }^{19}$

land-use patterns are evolving in Western Europe and Canada, where policies (most of them strongly favoring compact development) are very different").

18. This Article focuses on Western Europe, as opposed to Asia's more affluent nations or Eastern European nations, for two reasons. First, the above-cited defenders of the Inevitability Theory focus on Europe rather than Asia. See supra note 17. Second, because Western European nations are significantly more affluent than those in Eastern Europe, the Inevitability Theory is more relevant to Western Europe. See U.S. CENSUS Bureau, Statistical Abstract of the United States: 2008, at 819, 836 (127th ed. 2008) [hereinafter 2008 STATISTICAL ABSTRACT] (demonstrating that European countries with average national incomes of over $\$ 25,000$ were western European countries such as Germany, Italy, Spain, and the United Kingdom).

19. A full discussion of possible remedies for the ill effects of sprawl is beyond the scope of this Article. The issue, however, has been amply addressed elsewhere and will be briefly addressed below. See, e.g., Michael E. Lewyn, You Can Have It All: Less Sprawl and Property Rights Too, TEMP. L. REV. (forthcoming 2008), available at http://works. bepress.com/lewyn/41/ (proposing deregulation of land use and reduced government 


\section{DOES EUROPE SpRAWL JUST LIKE AMERICA?}

\section{A. The Storytelling Behind the Inevitability Theory}

The Inevitability Theory rests upon a story about history: the claim that "low-density suburban development [] has been a persistent feature in cities since the beginning of urban history." 20 According to this theory, whenever "residents become more affluent, urban densities decrease and suburban growth increases." 21 Like American cities, European cities developed suburbs as early as the nineteenth century, and in recent years, some European cities have continued to decentralize. ${ }^{22}$ Between 1970 and 2000, cities as diverse as Glasgow, Liverpool, Marseilles, Milan, Naples, and Paris lost population while their suburbs gained population. ${ }^{23}$ As Europe suburbanized, it allegedly became more automobile-orientedcar ownership and per capita driving in European countries increased significantly in the second half of the twentieth century, ${ }^{24}$ while transit ridership stagnated. $^{25}$

spending on suburban highway construction); see infra Part IV (summarizing some proposals); James A. Kushner, The Post-Automobile City: Legal Mechanisms to Establish the Pedestrian-Friendly City 71-73, 102-07 (2004) (proposing more interventionist solutions such as limiting development to already-settled areas and to areas near public transit, increasing government support for public transit and bicycle paths, and imposing taxes to discourage automobile use).

20. See Garnett, supra note 13, at 604 (internal quotation marks omitted) (quoting BRUEGMANN, supra note 4, at 18).

21. Id. (citing BRUEGMANN, supra note 4, at 24).

22. Id. (citing BRUEGMANN, supra note 4, at 90-93); BRUEGMANN, supra note 4, at 92 ("[M]ost European cities continue to decentralize . . . . [T] he parts of suburban Phoenix that have developed in the past ten or twenty years are actually quite comparable to the Parisian suburbs that have grown at the same time.").

23. See Hank Savitch, Dreams and Realities: Coping with Urban Sprawl, 19 VA. EnVTL. L.J. 333, 342 (2000) (detailing that by 2000, Glasgow and Liverpool lost 38\% of their 1970 population, Milan 27\%, Naples 15\%, Marseilles 13\%, Paris 10\%; metropolitan areas of Glasgow, Liverpool, Naples, Marseilles, and Paris gained population during this period; and the Milan region lost population at a slower rate than the city did); TRANSP. RESEARCH BD., MAKING TRANSIT WORK: INSIGHT FROM WESTERN EUROPE, CANADA, AND THE UNITED STATES 47 (2001), http://onlinepubs.trb.org/onlinepubs/sr/sr257.pdf [hereinafter MAKING TRANSIT WORK] (finding that in Belgium, Great Britain, Luxembourg, the Netherlands, and West Germany, $78 \%$ of central cities lost population in the late 1970s).

24. MAKING TRANSIT WORK, supra note 23, at 59 (indicating that between 1960 and 1995 , the number of cars per 1000 people nearly sextupled in West Germany, nearly quadrupled in France, more than tripled in Great Britain and the Netherlands, and more than doubled in Belgium); see also O'Toole, supra note 17, at 108 ("Between 1960 and $1990, \ldots$. per capita driving in European urban areas such as Brussels, Copenhagen, Hamburg, London, and Paris increased by two to five times.").

25. O'ToOLE, supra note 17, at 108-09 (explaining that the "1990 per capita transit ridership in those same areas was about the same or less than in 1960, so transit's share of travel typically declined by 50 percent or more"). 
This story, however, overlooks two inconvenient truths. First, European cities, whatever their recent trends, are still sprawling far less than American cities. Second, it is no longer consistently the case that European cities have continued to decline in population, nor is it always the case that Europe has continued to become more automobile dependent in recent years.

\section{B. Flaw One in the Story: Europe Does Not Sprawl Like the United States}

Table 1 below compares the United States with several European countries.

TABLE 1

PERCENT OF TRIPS TAKEN BY SEVERAL MODES ${ }^{26}$

\begin{tabular}{|l|l|l|l|l|l|}
\hline & Auto & $\begin{array}{l}\text { Public } \\
\text { Transit }\end{array}$ & Bicycle & $\begin{array}{l}\text { Other } \\
\text { (Including } \\
\text { Walking) }\end{array}$ & $\begin{array}{l}\text { Auto } \\
\text { Trips Per } \\
\text { Transit } \\
\text { Trip }^{27}\end{array}$ \\
\hline United States & 89 & 2 & 1 & 7 & 44.5 \\
\hline Canada & 76 & 10 & 2 & 12 & 7.6 \\
\hline Denmark & 42 & 14 & 20 & 24 & 3.0 \\
\hline Great Britain & 65 & 14 & 4 & 17 & 4.6 \\
\hline France & 56 & 13 & 5 & 25 & 4.5 \\
\hline Germany & 49 & 16 & 12 & 23 & 3.1 \\
\hline Netherlands & 45 & 7 & 28 & 20 & 6.4 \\
\hline Sweden & 46 & 11 & 10 & 33 & 4.2 \\
\hline Switzerland & 46 & 20 & 9 & 26 & 2.3 \\
\hline
\end{tabular}

As Table 1 shows, Europeans are far less automobile dependent than Americans, and they use public transit far more than Americans. In the United States, there are 44.5 auto trips taken per transit trip; by contrast, in Switzerland, there are only 2.3 auto trips per transit trip. ${ }^{28}$

Bruegmann argues that even in the Netherlands, "cars now account for the vast majority of all vehicular trips; public transportation, in fact,

26. See MAKING Transit Work, supra note 23, at 30.

27. This figure was apparently determined by dividing the automotive mode share by the transit mode share. Therefore, because the United States has an $89 \%$ "auto mode share" and a $2 \%$ "transit mode share," its auto-to-transit ratio is 44.5. Id.

28. Id. 
accounts for less than 10 percent of commuting trips." ${ }^{29}$ But Bruegmann's emphasis on "vehicular" trips camouflages another major difference between the United States and European countries: the frequency of nonvehicular trips in parts of Europe. In the Netherlands and some other European nations, walking and biking trips are far more common than public transit trips. ${ }^{30}$ Although the Dutch drive more often than they use public transport, they walk or bike as often as they drive: $28 \%$ of all Dutch trips involve biking - as opposed to $1 \%$ of all American tripsand $20 \%$ of all Dutch trips involve walking or some other means of travelas opposed to only $7 \%$ of all American trips. ${ }^{31}$ Although Europeans do use public transit more than Americans, any statistical method that focuses solely on transit overlooks a key difference between Europe and the United States: In European cities, walking and biking, as well as public transit, are common travel options. ${ }^{32}$

Table 1 includes Europe's rural and suburban areas, but urban Europe is also far less automobile dependent than the United States. Table 2 below compares a selection of European and American cities.

29. See BrUEGMANn, supra note 4, at 202 (citing Christian GERONDEAU, TranSPORT IN EUROPE 222 fig.3 (1997)).

30. See MAKING TRANSIT Work, supra note 23, at 30.

31. Id. (explaining that the "other" category includes not just walking, but also school buses, motorcycles, and paratransit).

32. Id. 
TABLE 2

PERCENTAGE OF JOURNEYS TO WORK BY CAR, WESTERN EUROPEAN AND AMERICAN CITIES WITH POPULATION OF OVER ONE MILLION PEOPLE ${ }^{33}$

\begin{tabular}{|l|l|}
\hline Austria & - \\
\hline Vienna & 41 \\
\hline Germany & - \\
\hline Berlin & 44 \\
\hline Hamburg & 51 \\
\hline Munich & 41 \\
\hline Italy & - \\
\hline Milan & 46 \\
\hline Naples & 53 \\
\hline Rome & 57 \\
\hline Spain & - \\
\hline Barcelona & 32 \\
\hline Madrid & 47 \\
\hline USA & - \\
\hline New York & 33 \\
\hline Los Angeles & 80 \\
\hline Chicago & 65 \\
\hline Phoenix & 89 \\
\hline Philadelphia & 62 \\
\hline Houston & 88 \\
\hline Dallas & 89 \\
\hline San Diego & 86 \\
\hline San Antonio & 91 \\
\hline & \\
\hline
\end{tabular}

33. See Urban Audit, City Profiles List, http://www.urbanaudit.org/CityProfiles.aspx (last visited Feb. 9, 2009) (detailing statistics for European cities; for details click on links for individual cities); U.S. CENSUS BuREAu, STATISTICAL ABSTRACT OF THE UNITED STATES: 2003, at 700 (2003) (indicating commuting statistics for the twenty-five largest cities in America in 2000); City Mayors Statistics, Europe's Largest Cities, http://www. citymayors.com/features/euro_cities1.html (last visited Feb. 9, 2009) (listing the most populous European cities); City Mayors Statistics, The Largest U.S. Cities, http://www. citymayors.com/gratis/uscities_100.html (last visited Feb. 9, 2009) (listing the most populous American cities). A Admittedly, these statistics involve only a few cities and some cities have been excluded due to the unavailability of data. However, other measurements involving a broader number of cities have reached similar results. See MAKING TRANSIT WORK, supra note 23, at 32 (showing that most European cities have over 100 yearly transit trips per person and a few have over 300 per person, while most American cities have fewer than 50 transit trips per person). 
Table 2 shows that the differences between American and European cities are as great as the differences between the United States and European nations as a whole. Even relatively transit friendly cities such as Chicago and Philadelphia are more automobile dominated than the larger European cities. ${ }^{34}$

In sum, it is simply not the case that European cities are identical to American cities. European cities have suburbs and cars just like American cities, but the differences in degree among European cities and the more automobile-dependent American cities are quite significant.

\section{Flaw Two in the Story: Europe Is Not Turning into the United States}

The Inevitability Theory, however, does not rest solely upon Europe's transit and pedestrian-friendly status quo. For example, using Hamburg, Germany as a case study, Bruegmann admits that residents there "enjoy many of the advantages of the nineteenth-century urban pattern." 35 The city's "vibrant historic core still dominates the region," and "[t]here is no widespread abandonment or urban decay and nothing resembling an American slum." 36 Nevertheless, Bruegmann argues that European cities such as Hamburg are experiencing "a continuing decline in population density in the historic core, a quickening of the pace of suburban and exurban development,",37 and that "European urban dwellers are using their cars more and using public transportation less." 38 This claim, however, is both factually and logically problematic.

\section{The Facts}

As noted above, European cities did experience considerable decentralization in the last half of the twentieth century. ${ }^{39}$ In recent years, however, European core cities have regained population: Between 1991 and 2004, population increased in fifteen of twenty-eight "core cities in European capitals." Of course, not all of these cities are comparable to American

34. See supra note 33 and accompanying Table 2.

35. BRUEGMANN, supra note 4 , at 200 .

36. Id. at 199 .

37. Id.

38. Id. at 202; see also O'ToOLE, supra note 17, at 264 ("[B]etween 1980 and 2000, the automobile's share of European passenger travel increased from 76 percent to 78 percent, whereas intercity rail and transit's share declined from 21 percent to 16 percent.") (citing EUROPEAN UNION, KEY FACTS AND FIGURES ABOUT THE EUROPEAN UNION 52 (2004), http://ec.europa.eu/publications/booklets/eu_glance/44/en-3.pdf).

39. See supra notes 22-23 and accompanying text.

40. See Eurostat European Comm'n, Eurostat Regional Yearbook: 2007, at 77 (2007) (listing the following cities as having gained population: Lefkosia, Cyprus; 
cities - some are not very large, and others are in less affluent Eastern European countries. Thus, these cities may not have faced the same decentralizing pressure as cities faced in wealthier countries. ${ }^{41}$ However, a look at the largest cities in affluent Western Europe shows that some big cities in Europe's more affluent nations also gained population.

TABLE 3

Population Changes In Western EuROPEAN Cities WITH OVER ONE MILLION PEOPLE (POPULATION IN MILLIONS)

\begin{tabular}{|l|l|l|l|l|}
\hline & $\begin{array}{l}\text { Early 1990s } \\
\text { Population }\end{array}$ & $\begin{array}{l}\text { Most Recent } \\
\text { Population } \\
\text { Estimate }\end{array}$ & $\begin{array}{l}\text { Percentage } \\
\text { Population } \\
\text { Growth }\end{array}$ & $\begin{array}{l}\text { Percentage } \\
\text { Population } \\
\text { Growth for } \\
\text { Metro Area }\end{array}$ \\
\hline $\begin{array}{l}\text { Vienna, } \\
\text { Austria }\end{array}$ & $1.539(1991)$ & $1.664(2007)$ & +8 & +5 \\
\hline $\begin{array}{l}\text { London, United } \\
\text { Kingdom }\end{array}$ & - & - & - & - \\
\hline $\begin{array}{l}\text { (Inner London } \\
\text { only) }\end{array}$ & $2.599(1991)$ & $2.985(2005)$ & +14 & +8 \\
\hline
\end{tabular}

Helsinki, Finland; Stockholm, Sweden; London, England; Copenhagen, Denmark; Amsterdam, Netherlands; Brussels, Belgium; Dublin, Ireland; Paris, France; Vienna, Austria; Athens, Greece; Madrid, Spain; Valletta, Malta; Warsaw, Poland; and Luxembourg).

41. See supra notes 14-16 and accompanying text describing the theory that sprawl is a result of increasing wealth; see also supra note 18 stating that Western Europe is more affluent than Eastern Europe.

42. Thomas Brinkhoff, City Population: Austria, http://www.citypopulation.de/ Oesterreich-Cities.html (last visited Feb. 9, 2009). Regional statistics for Austria were unavailable and, therefore, the population of the nation as a whole was used as a substitute. But, because approximately twenty percent of Austria's population lives in Vienna, this statistic may well be comparable to regional or metropolitan area populations in larger nations. Id. (illustrating that as of 2007 , nearly 1.7 million of Austria's 8.3 million inhabitants lived in Vienna).

43. Thomas Brinkhoff, City Population: Great Britain and Northern Ireland, http://www.citypopulation.de/UK-UA.html (last visited Feb. 9, 2009) (demonstrating that between 1991 and 2001, the population of London's urban area grew from 7.651 million to 8.278 million); Wikipedia, Inner London, http://en.wikipedia.org/wiki/Inner London (last visited Feb. 9, 2009) (Inner London statistics). 


\begin{tabular}{|l|l|l|l|l|}
\hline Paris, France $^{44}$ & $2.152(1990)$ & $2.166(2005)$ & +1 & +8 \\
\hline Germany & - & - & - & - \\
\hline Berlin $^{45}$ & $3.471(1995)$ & $3.404(2006)$ & -2 & +3 \\
\hline Hamburg $^{46}$ & $1.707(1995)$ & $1.754(2006)$ & +2 & +1 \\
\hline Munich $^{47}$ & $1.236(1995)$ & $1.294(2006)$ & +4 & +1 \\
\hline Italy & - & - & - & - \\
\hline Milan $^{48}$ & $1.369(1991)$ & $1.303(2007)$ & -5 & +7 \\
\hline Naples $^{49}$ & $1.067(1991)$ & $0.975(2007)$ & -9 & +2 \\
\hline Rome $^{50}$ & $2.775(1991)$ & $2.705(2007)$ & -2 & +6 \\
\hline Spain $^{\text {Barcelona }}$ & - & - & - & - \\
\hline Madrid $^{51}$ & $1.643(1991)$ & $1.595(2007)$ & -2 & +23 \\
\hline
\end{tabular}

Of the eleven large cities listed above, six gained population during the 1990s. ${ }^{53}$ In fact, Hamburg, London, Munich, and Vienna all grew

44. Thomas Brinkhoff, City Population: France, http://www.citypopulation.de/ France-Cities.html (last visited Feb. 9, 2009) (showing statistics for both the city of Paris and Ile-de-France, the region containing Paris, which grew from 10.66 million to 11.577 million between 1990 and 2007).

45. Thomas Brinkhoff, City Population: Berlin, http://www.citypopulation.de/ Deutschland-Berlin.html (last visited Feb. 9, 2009); Thomas Brinkhoff, City Population: Germany, http://www.citypopulation.de/Deutschland-Agglo.html (last visited Feb. 9, 2009) [hereinafter Brinkhoff, Germany] (indicating that between 1995 and 2005, the population of the Berlin "agglomeration" grew from 4.064 million to 4.2 million).

46. Brinkhoff, Germany, supra note 45 (indicating that between 1995 and 2005, the population of the Hamburg agglomeration grew from 2.457 million to 2.549 million); Thomas Brinkhoff, City Population: Hamburg, http://www.citypopulation.de/DeutschlandHamburg.html (last visited Feb. 9, 2009).

47. Thomas Brinkhoff, City Population: Bayern, http://www.citypopulation.de/ Deutschland-Bayern.html (last visited Feb. 9, 2009); Brinkhoff, Germany, supra note 45 (indicating that between 1995 and 2005, the population of the Munich agglomeration grew from 1.86 million to 1.94 million).

48. Thomas Brinkhoff, City Population: Italy, http://www.citypopulation.de/ItalyCities.html\#Stadt_alpha (last visited Feb. 9, 2009) [hereinafter Brinkhoff, Italy] (indicating also that between 1991 and 2007, the population of Lombardia, the region containing Milan, grew from 8.856 million to 9.545 million).

49. Id. (indicating that between 1991 and 2007, the population of Campania, the region containing Naples, grew from 5.63 million to 5.79 million).

50. Thomas Brinkhoff, City Population: Italy: Lazio, http://www.citypopulation.de/ Italy-Lazio.html (last visited Feb. 9, 2009) (indicating that between 1991 and 2007, the population of Lazio, the region containing Rome, grew from 5.14 million to 5.493 million).

51. Thomas Brinkhoff, City Population: Spain, http://www.citypopulation.de/SpainCities.html (last visited Feb. 9, 2009) (indicating also that the population of Cataluna, the region containing Barcelona, grew from 6.059 million to 7.21 million).

52. Id. (indicating also that between 1991 and 2007, the population of Madrid, the region containing the city of Madrid, grew from 4.947 million to 6.081 million).

53. See supra notes $42-52$ and accompanying Table 3 . 
faster than their surrounding regions, and thus faster than their suburbs. ${ }^{54}$ By contrast, in the United States, only two of the nation's ten biggest cities grew faster than their suburbs during the 1990s. ${ }^{55}$

Of the five European cities that were population losers, most lost population by very small margins: Only one city, Naples, lost over 5\% of its 1990 population, and no city lost as much as $10 \%{ }^{56}$ By contrast, America's fastest declining large city, Detroit, had lost almost $16 \%$ of its 1990 population by $2006,{ }^{57}$ despite the fact that metro Detroit's population grew by about $5 \%,{ }^{58}$ a rate comparable to that of several of the European regions listed above. ${ }^{59}$

Even if European cities' populations have grown, it could nevertheless plausibly be argued that Europe is evolving towards American style sprawl if those cities have continued to evolve towards automobiledependent development. European transit ridership statistics, however, suggest otherwise.

54. Id.

55. See Alan Berube, Gaining but Losing Ground: Population Change in Large Cities and Their Suburbs, in 1 RedEFINING URban AND SUBURBAn AMERICA: EvidENCE FROM CENSUS 2000, at 33, 47-49 (Bruce Katz \& Robert E. Lang eds., 2003) (listing the largest cities and comparing each city's population growth with that of its suburbs; of the ten largest cities, only New York and San Antonio had city growth rates that exceeded their suburban growth rates during the 1990s).

56. See supra notes $42-52$ and accompanying Table 3.

57. See 2008 STATISTICAL ABSTRACT, supra note 18, at 32 (indicating that the population declined from 1.028 million in 1990 to 871,000 in 2006). Note however, that most other American cities of Detroit's size actually grew: Of the other seven cities that had a population of over one million people in 1990 - Chicago, Dallas, Houston, Los Angeles, New York, Philadelphia, and San Diego - only Philadelphia lost population during the 1990 s and early 2000s. Id. at 32-33.

58. Id. at 25 (indicating that the population grew from 4.249 million to 4.469 million between 1990 and 2006); Berube, supra note 55, at 49-50 (listing other examples of American cities that declined in population while their suburbs grew).

59. See supra notes $42-52$ and accompanying Table 3 . 
TABLE 4

BILLIONS OF PASSENGER-KILOMETERS OF BUS, TRAM, AND RAIL TRANSPORTATION COMBINED, LARGE WESTERN EUROPEAN ${ }^{60}$ NATIONS $^{61}$

\begin{tabular}{|l|l|l|l|}
\hline & $\mathbf{1 9 9 5}$ & $\mathbf{2 0 0 6}$ & Percent Increase \\
\hline Germany & 153.9 & 160.8 & 4.5 \\
\hline Spain & 60.5 & 77.7 & 28.4 \\
\hline France & 106.1 & 136.4 & 28.6 \\
\hline Italy & 136.3 & 155.2 & 13.9 \\
\hline United Kingdom & 81.4 & 106.1 & 30.3 \\
\hline
\end{tabular}

In each of Europe's five largest countries, bus and rail ridership

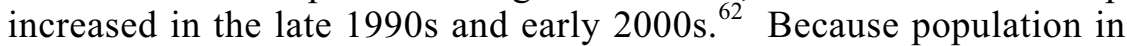
each of these countries increased by no more than $10 \%$ during this period, it appears that per capita ridership increased in every country but Germany. ${ }^{63}$ Similarly, transit ridership for the European Union as a

60. This table lists countries that: (a) were members of the European Union before 2004, thereby excluding less affluent Eastern European nations that joined the European Union in recent years; and (b) have over twenty million inhabitants, thereby excluding smaller nations such as Austria, Greece, and Belgium. See WHO Oral Health, Countries of European Union, http://www.whocollab.od.mah.se/euro/eu/euronational.html (last visited Feb. 9, 2009) [hereinafter WHO Oral Health] (listing European nations by date of entry into the European Union); see supra note 18 and accompanying text illustrating that Western European nations are more affluent than Eastern European nations. Arguably, because the United States is larger and more affluent than most European nations, the larger, more affluent European countries are the nations most comparable to the United States. See 2008 STATISTICAL ABSTRACT, supra note 18, at 825-27 (demonstrating that the only nations more populous than the United States are China and India); see also id. at 836 (indicating that the United States is wealthier than most European nations).

61. See European COMM'n, EU EnERgy And Transport in Figures: Statistical PoсKетвоOK 2007, pts. 3.3.5, 3.3.6, 3.3.7, available at $\mathrm{http}: / / \mathrm{ec}$.europa.eu/dgs/energy transport/figures/pocketbook/2007 en.htm (last visited Jan. 13, 2009) (click on "Part 3" link, then select tables 3.3.5, 3.3.6, and 3.3.7).

62. See supra notes 60-61 and accompanying Table 4 .

63. Id. Because not every country conducted a census at the same time, their exact populations for 1995 and 2006 are unknown. See United NATIONS StATISTICS Div., 2010 World Population ANd Housing Census Programme, http://unstats.un.org/ unsd/demographic/sources/census/censusdates.htm\#(14) (last visited Feb. 9, 2009) (listing dates of various nations' censuses). But, in all five countries, populations from 1990 to 2003 increased by between $2 \%$ and $6 \%$. See 2008 StATISTICAL ABSTRACT, supra note 18, at 814-16 (indicating that between 1990 and 2008, the population of France increased from 58.2 million to 64.1 million; the population of Germany increased from 79.4 million to 82.4 million; the population of Italy increased from 56.7 million to 58.1 million; the population of Spain increased from 39.4 million to 40.4 million; and the population of the United Kingdom increased from 57.5 million to 60.9 million). 
whole increased from 920 million passenger-kilometers to 991 million passenger-kilometers. ${ }^{64}$

Indeed, transit ridership has increased even where population is suburbanizing. Although most of Europe's largest cities have gained population, all three of Italy's largest cities have continued to lose residents in recent years. ${ }^{65}$ Yet, Italian transit ridership increased by $13.9 \%$ between 1995 and $2006,{ }^{66}$ and the percentage of trips taken by car has stagnated over the past decade. ${ }^{67}$

It could be argued that even if transit ridership has increased, Europe has nevertheless become more car dependent because automobile use has risen even faster than transit ridership. This was apparently the case for much of the twentieth century; ${ }^{68}$ however, evidence from recent years is more ambiguous, as Table 5 reveals below.

TABLE 5

AUTOMOBILE SHARE OF MOTORIZED PASSENGER TRANSPORTATION, LARGE WESTERN EUROPEAN NATIONS ${ }^{69}$

\begin{tabular}{|l|l|l|}
\hline & 1995 & 2006 \\
\hline Germany & 85.4 & 85.7 \\
\hline Spain & 82 & 82.6 \\
\hline France & 86.8 & 85.3 \\
\hline Italy & 82.4 & 81.9 \\
\hline UK & 89.2 & 87.4 \\
\hline
\end{tabular}

In three of Western Europe's five largest nations, the automobile's share of passenger miles traveled actually declined between 1995 and

64. See EuROPEAN COMM'N, supra note 61, tbl.3.3.2.

65. See Table 3 supra pp. 95-96.

66. See Table 4 supra p. 98.

67. See Table 5 infra p. 99.

68. See supra notes 24-25 and accompanying text.

69. See Eurostat, CAR Share Of Inland PASSEnger Transport, http://epp. eurostat.ec.europa.eu/portal/page?_pageid $=1996,45323734 \&$ dad $=$ portal\&_schema $=$ PO RTAL\&screen $=$ welcomeref\&open $=/ \&$ product $=E U$ TB transport\&depth $=2$ (expand "Transport, volume and modal split," click on the figures for "Car share of inland passenger transport") (last visited Feb. 9, 2009) [hereinafter TRANSPORT TABLE]. This table is based solely on "transport by passenger cars, buses and coaches, and trains." Id. Because Table 5 does not include transport by foot and bicycle, the automobile mode shares listed in Table 5 are higher than in Table 1 above. 
$2006 .^{70}$ In the other two, the automobile's mode share increased by less than $1 \%{ }^{71}$ It follows that in Europe's largest, most affluent nations, the trend towards automobile dependence has slowed or halted. The same is also true for Europe's smaller countries: In the fifteen nations comprising the European Union before 2004, the automobile's mode share has fluctuated between $84.3 \%$ and $85 \%$ every year since $1995^{72}$ and the current auto mode share is $84.3 \%{ }^{73}$ In sum, it is simply not the case that Europe is adopting American style sprawl.

To the extent that Europe and the United States are converging, it may be the case that America is becoming more like Europe rather than vice versa. In 2007, Americans took 10.3 billion trips on public transit-the highest number in fifty years. ${ }^{74}$ Between 1995 and 2007, transit ridership rose by $32 \%$-more than double the growth rate of the American population. ${ }^{75}$ Moreover, as gasoline prices continued to explode in early 2008 , the number of miles driven by Americans decreased ${ }^{76}$ and transit ridership increased. ${ }^{77}$

\section{The Logic}

To the extent that European cities have continued to sprawl in recent years, this trend does not prove that Europe will inevitably become as sprawling and automobile dependent as America. The Inevitability Theory is based on the premise that a trend is irreversible, and therefore that if $X$-here, European cities and suburbs - is trending in the direction of $Y$-here, American-style sprawl, $X$ will inevitably become similar to $Y$. But this theory leads to absurd results. As noted above, transit ridership

70. Id.

71. Id.

72. Id. (listing share for "EU," consisting of fifteen countries). Because the EU had fifteen countries before admitting former Soviet-bloc nations, it can be assumed that these figures refer to the EU pre-2004 membership. See WHO Oral Health, supra note 60 .

73. TRANSPORT TABLE, supra note 69.

74. Tim Doulin, Coping with Nearly $\$ 3.45$ a Gallon; Save on Gas: Park Your Car, Columbus DisPatch, Mar. 13, 2008, at B1, available at 2008 WLNR 4913069.

75. Melanie Turner, Public Transit Ridership Reaches Highest Level in 50 Years, SACRAMENTO BuS. J., Mar. 10, 2008, available at http://sacramento.bizjournals.com/ sacramento/stories/2008/03/10/daily9.html.

76. Lynne Funk, Transportation: Gas Tax Revenue Could Be a Shrinking Asset, Officials Warn, BOND BUYER, June 25, 2008, at 5, available at 2008 WLNR 11880832 (stating that "there has been a national decline in vehicle miles traveled" for six months in a row); Richard Simon, Public Transit on Front Burner, L.A. TIMES, June 27, 2008, at A20, available at 2008 WLNR 12097080 (describing that commuters increasingly turn to public transit because of "soaring gasoline prices," and that in the first quarter of 2008 , "vehicle-miles traveled on the nation's roads declined 2.3\%").

77. Jay Bookman, Our Opinion: A Special Editorial; Drilling Down on Oil, Atlanta J.-CONST., June 22, 2008, at C4 (describing increases in transit ridership). 
in the United States has risen over the past decade or so. ${ }^{78}$ Thus, the United States may be trending away from car dependency and towards higher transit use. If all such trends were irreversible, though, one could conclude that the trend towards transit ridership would eventually culminate in the disappearance of the private automobile from the United Statesobviously a highly unlikely event.

Such overreliance on trends leads to absurd results in any context. For example, in 2004 President Bush received $71.5 \%$ of Utah's votes. ${ }^{79}$ If the 2008 Republican nominee receives only $65 \%$ of Utah's votes and the 2012 Republican nominee receives only $60 \%$, does that mean Utah will inevitably become as Democratic as New Jersey or New York? ${ }^{80}$ Not necessarily - the differences between Utah and New York are so great that Utah's present status as a Republican bastion has more predictive value than its trend towards the Democratic Party. Similarly, the differences between the pedestrian-friendly Netherlands - where less than half of all trips involve a private automobile ${ }^{81}$ —and the United States - where $87 \%$ of all trips involve automobiles ${ }^{82}$ - are so great that even if Dutch cities become significantly more automobile-oriented, they are unlikely to resemble automobile-dependent American cities, such as San Antonio. ${ }^{83}$

\section{EVEn In EUROPE, SOME GOVERNMENT POLICIES CREATE SPRAWL}

Even if Europe had been inexorably trending towards sprawl for decades, this result would not prove the Inevitability Theory. As Table 6 suggests, European sprawl, like American sprawl, has arisen at least partially from government policy.

78. See supra notes 74-77 and accompanying text.

79. See 2008 STATISTICAL ABSTRACT, supra note 18, at 243.

80. Id. (showing that Democratic nominees carried both states in 2000 and 2004).

81. See VICTORIA TRANSPORT POL'Y INST., WALKABILITY IMPROVEMENTS: STRATEGIES TO MAKE WALKING CONVENIENT, SAFE AND PLEASANT tbl.1, available at http://www.vtpi.org/ tdm/tdm92.htm (last visited Feb. 9, 2009).

82. Mark R. Norman, Burton W. Marsh Distinguished Service Award: Make No Little Plans, 78 InST. TRANSP. ENG'RS J. 22, 23 (2008) ("[Eighty-seven] percent of passenger trips are made in private vehicles.").

83. See Table 2 supra p. 93 illustrating that in San Antonio, 90\% of all commutes involve an automobile. 
TABLE 6

MILES OF LIMITED-ACCESS HigHWAYS ${ }^{84}$

IN MAJOR EUROPEAN COUNTRIES ${ }^{85}$

\begin{tabular}{|l|l|l|}
\hline & $\mathbf{1 9 7 0}$ & $\mathbf{2 0 0 5}$ \\
\hline Germany & 6061 & 12,363 \\
\hline France & 1553 & 10,804 \\
\hline Italy & 3913 & 6542 \\
\hline Spain & 387 & 11,432 \\
\hline United Kingdom & 1183 & 3634 \\
\hline
\end{tabular}

Table 6 shows that European governments have increased the size of their highway networks in recent decades, and increases ranged from about a two-thirds increase in Italy to almost a thirtyfold increase in Spain. ${ }^{86}$

And where highway systems grow, sprawl grows. If a government builds a highway leading to a suburb, the highway makes it easier for drivers to commute to and from that suburb, thus causing people and their employers to move to that suburb from cities and established suburbs. $^{87}$ As one American court has noted, "[h]ighways create demand for travel and expansion by their very existence." 88 In Europe, as in America, some development has moved to areas near highways. For example, pro-sprawl commentators Peter Gordon and Harry Richardson describe one 1990s Swedish development as a "vast linear Edge City of business parks and hotels and out-of-town shopping centres, stretching

84. The European Commission's Statistical Pocketbook uses the term motorway. See EUROPEAN COMM'N, supra note 61, pt. 3.5. A motorway, however, is essentially a limited-access highway. See OECD, Glossary of Statistical Terms: Motorway, http://stats. oecd.org/glossary/detail.asp?ID=4008 (last visited Feb. 9, 2009) (defining motorway as a road "specially designed and built for motor traffic, which does not serve properties bordering on it ....").

85. See EUROPEAN COMM'N, supra note 61, tbl.3.5.1.

86. Id.

87. See Todd Litman, Victoria Transport Pol'y Inst., Generated Traffic AND INDUCED TRAVEL: IMPLICATIONS FOR TRANSPORT PLANNING 4-11 (2009), http://www. vtpi.org/gentraf.pdf (summarizing numerous studies showing that highway expansion increases traffic by making driving more convenient, and stimulates more dispersed development on urban fringe); Michael E. Lewyn, Suburban Sprawl: Not Just an Environmental Issue, 84 MARQ. L. REV. 301, 318-22 (2000) (discussing the issue in detail and describing a survey revealing that would-be homebuyers valued proximity to a highway above other amenities).

88. Sierra Club v. U.S. Dep’t of Transp., 962 F. Supp. 1037, 1043 (N.D. Ill. 1997) (citing Swain v. Brinegar, 517 F.2d 766, 777 (7th Cir. 1975)). 
along the E4 highway, for twelve miles and more . . .."89 If there had been no E4 highway, landowners might never have built this "Edge City," and its businesses and hotels might be located in a more traditionally urban location. And, if such highway-created suburbs lack adequate public transit, their road-driven growth will increase societal automobile dependence by reducing transit ridership because the people who move to that suburb or take jobs in that suburb will only be able to get around by car. ${ }^{90}$

It follows that where European cities have sprawled, such sprawl is at least partially the result not of some inexorable desire of affluent people for suburbia, but because of government policies that encouraged sprawl by paying for highways which opened up suburban real estate for development. Thus, even if there had been no European reurbanization in recent years, the existence of European sprawl would not prove the Inevitability Theory.

As noted above, European cities have sprawled less than American cities. $^{91}$ But if European road networks were smaller, European cities would be even less sprawling still and would be even more oriented towards nondrivers.

\section{CAN THE United States SpRaWl Less?}

Even if suburban sprawl is less common in Europe than in the United States, it could be argued that the policies that limit sprawl in Europe would be impractical in the United States. For example, some European countries discourage driving by imposing heavy gasoline taxes, causing fuel to cost as much as six dollars per gallon; ${ }^{92}$ such a practice is unlikely to be politically feasible in the United States. ${ }^{93}$ European governments also

89. See GORDON \& RichARDSON, supra note 17, at 3. Gordon and Richardson are characterized as "pro-sprawl commentators" because in the opening of their essay, they proclaim that the "assertions by the critics of urban sprawl do not stand up to scrutiny." Id. at 1 .

90. See Blackwell, supra note 8, at 1279 (explaining that in the United States, the majority of new jobs in the suburbs are not accessible by public transit); Wendell Cox, The Sierra Club Attempts to Stop I-355 Expansion in Illinois, Aug. 5, 2002, available at http://www.absillinois.com/build53/article.pdf ("Parisians who live in the suburbs have little auto-competitive transit service" to suburban jobs).

91. See supra Part II.

92. See Samantha A. Krasner, Note, America's Addiction to Oil: A Comprehensive Strategy for Reducing Our Nation's Dependence, 40 CoNN. L. REV. 209, 229 (2007).

93. Id. at 230 (explaining that fuel tax increases are especially unpopular in the United States partially because Americans are so dependent on vehicles); Justin Fox, 
regulate commerce and real estate development more than Americans might like-for example, by restricting the growth of large retailers to protect small urban retailers, ${ }^{94}$ by paying farmers not to sell land to developers, ${ }^{95}$ and by directly prohibiting development of rural land ${ }^{96}$ Because Americans are less tolerant of government intervention in the economy than Europeans, ${ }^{97}$ it could be argued that such policies are politically impossible in the United States and, therefore, it is equally impossible for the United States to reduce sprawl in any significant respect.

This argument lacks merit for two reasons. First, even the European countries with the highest levels of economic freedom are far less automobile dependent than the United States. ${ }^{98}$ Thus, it is possible that Americans can reduce automobile dependence without making government significantly larger or more intrusive. Second, Americans can adopt several policy options that would create more pedestrian-friendly cities without increasing government regulation of the economy.

\section{A. Less Government, Less Sprawl Too}

As noted above, Europeans tend to be more heavily taxed and regulated than Americans in a variety of aspects. ${ }^{99}$ Thus, it could be argued that if

How the Next President Should Fix the Economy, Time, May 26, 2008, at 40 (describing America's political reluctance regarding increased fuel taxes).

94. See Pietro S. Nivola, Are Europe's Cities Better? (1999), http://www. brookings.edu/articles/1999/fall_europe nivola.aspx ("Multiple restrictions on the penetration and predatory pricing practices of large retailers in various European countries protect small urban businesses.").

95. Id. ("[L]avish agricultural subsidies in Europe have kept more farmers in business and dissuaded them from selling their land to developers.").

96. See James A. Kushner, Growth for the Twenty-First Century-Tales from Bavaria and the Vienna Woods: Comparative Images of Planning in Munich, Salzburg, Vienna, and the United States, 29 URB. LAw. 911,912 (1997) ("Under Austrian and German law, conversion of rural land for urban development is nearly impossible.").

97. The Heritage Foundation, a conservative research organization, has ranked the United States fifth in the world in "economic freedom," ahead of every European country except Ireland. See Kim R. Holmes ET AL., 2008 InDEX OF ECONOMIC FREEDOM 9 (2008), http://www.heritage.org/research/features/index/countries.cfm; Reva B. Siegel, The New Politics of Abortion: An Equality Analysis of Woman-Protective Abortion Restrictions, 2007 U. ILL. L. REV. 991, 1005 n.60 (describing Heritage as "an influential conservative think tank"). Furthermore, the United States is tied for first in strength of property rights, indicating that property rights are more heavily protected in the United States than in other countries. See Daniel H. Cole, Political Institutions, Judicial Review, and Private Property: A Comparative Institutional Analysis, 15 SUP. CT. ECON. REV. 141, 171-72 (2007) (describing the Index in more detail and pointing out that the United States consistently ties for the highest "property rights" ranking in the Index of Economic Freedom).

98. See infra Part IV.A.

99. See supra notes $92-96$ and accompanying text. 
Europe had America's low levels of taxes and regulation, it too would suffer from American style sprawl. This argument, however, lacks merit because some European countries, most notably Ireland and Switzerland, have managed to combine modest government and compact development.

Ireland, which ranks ahead of the United States on the Heritage Foundation's Index of Economic Freedom, ${ }^{100}$ protects property rights as much as the United States ${ }^{101}$ and has lower government spending than the United States. ${ }^{102}$ Yet, Irish cities are far less automobile dependent than the United States. In Dublin, Ireland's largest city, ${ }^{103}$ only $40 \%$ of all trips are by car-fewer than in any American city other than New York. ${ }^{104}$ Between 1996 and 2006, Dublin's population grew by about $6 \%$, from just over 481,000 to just over $506,000{ }^{105}$ Although Ireland's automobile travel has grown more rapidly in recent years than other modes of transportation, ${ }^{106}$ the automobile's national share of motorized travel $^{107}$ is $76.1 \%$, which is still lower than more heavily regulated nations such as France and Germany. ${ }^{108}$

Similarly, Switzerland combines a relatively laissez-faire polity and a relatively high level of pedestrian-friendly development. Swiss government spending consumes $35.8 \%$ of GDP, ${ }^{109}$ slightly less than American government spending, ${ }^{110}$ and the Heritage Foundation asserts that Switzerland has the

100. See Holmes ET AL., supra note 97, at 9 (listing Ireland as the only European nation that ranks ahead of the United States).

101. Id. at 220, 386 (indicating that both nations have "Property Rights" scores of $90 \%)$.

102. Id. (indicating that in 2007, government spending-which is measured as a percentage of Gross Domestic Product, or GDP - equaled 34.4\% of GDP in Ireland as opposed to $36.6 \%$ of GDP in the United States).

103. See Thomas Brinkhoff, City Population: Ireland, http://www.citypopulation. de/Ireland.html (last visited Feb. 9, 2009) [hereinafter Brinkoff, Ireland].

104. See Urban Audit, supra note 33 (listing statistics for Dublin); see supra Table 2 on p. 93 (listing statistics for New York City).

105. See Brinkhoff, Ireland, supra note 103. However, population did decline in Cork, Ireland's second largest city and only other city with over 100,000 residents. Id. (indicating that the population of Cork declined from 127,187 to 119,418).

106. See TRANSPORT TABLE, supra note 69 (indicating that the automobile share of inland passenger transport grew from $70.6 \%$ to $76.1 \%$ between 1995 and 2006).

107. See id. (explaining Mode Share Transport Table).

108. See supra Table 5 on p. 99 (showing that the automobile share of motorized travel exceeds $80 \%$ in both nations); HOLMES ET AL., supra note 97, at 9-10 (showing that according to the Heritage Foundation, Germany ranks twenty-third in the world in economic freedom, and France ranks forty-eighth).

109. HOLMES ET AL., supra note 97, at 356.

110. Id. at 386 (indicating that America devoted $36.6 \%$ of GDP to government spending in 2007). 
world's ninth freest economy. ${ }^{111}$ Yet, the Swiss are even more likely to use public transit than other Europeans, let alone Americans. ${ }^{112}$

If Europe's pedestrian-friendly development resulted from Europe's high taxes and high levels of government spending and regulation, the European countries with the lowest levels of taxation and regulation would be the most sprawling, automobile-dependent nations in Europe. However, the examples of Ireland and Switzerland suggest that this is not the case. ${ }^{113}$

\section{B. A Way Out}

Even if European nations are able to create compact, pedestrian-friendly cities, it might be the case that, for one reason or another, the United States is unable to create European style cities without aggressive government regulation. ${ }^{114}$ Obviously, there is no way of knowing exactly how much effect any given policy might have on American urban form. However, American state and local governments could adopt a wide variety of policies that could succeed in limiting sprawl without increasing taxes or regulation. For example:

- American zoning law has historically sought to reduce population density through regulations requiring homes and apartments to consume large amounts of land. ${ }^{115}$ Such

111. Id. at 9 .

112. See supra Table 1 on p. 91.

113. It could be argued that despite its overall high level of economic freedom, Switzerland regulates land use more intensively than the United States. However, it is not clear that this is the case. Although Swiss law strongly discourages development in the countryside, Swiss zoning law, unlike American law, does not require landowners to segregate housing from other land uses. See Matthew A. Light, Note, Different Ideas of the City: Origins of Metropolitan Land-Use Regimes in the United States, Germany, and Switzerland, 24 YALE J. INT'L L. 577, 592-95 (1999) (discussing Swiss land use regulation in detail). Thus, it is unclear whether, on balance, Swiss regulation is more intrusive or less intrusive than American regulation. Irish land use policy is apparently fairly permissive. See Building on Poor Foundations, IRISH TIMES, Jan. 24, 2007, at 13, available at 2007 WLNR 1351978 (noting that the Irish government's "laissez-faire approach" to urban planning has led to increased urban sprawl). Ireland, however, does promote public transit use through an elaborate rail system. See Wikipedia, Rail Transport in Ireland, http://en.wikipedia.org/wiki/Rail_transport_in_Ireland (last visited Feb. 9, 2009)

114. For example, it could be argued that the sheer size of the United States facilitates suburban development simply because the United States has more land to develop. Cf. Richard I. Fine \& Francois Alland, Current Political and Economic Developments in the European Union, 18 WhitTIER L. REV. 281, 282 (1997) ("The European Union is composed of fifteen countries that cover only half of the square miles of the United States, yet it is more populated.").

115. See Agins v. City of Tiburon, 447 U.S. 255, 257, 261-63 (1980) (upholding zoning ordinance allowing construction of only one house per acre); STOEBUCK \& 
antidensity regulations reduce transit use, because only compact neighborhoods have large numbers of people living within walking distance of bus or train stops. ${ }^{116}$ For the same reason, low-density areas are uncomfortable for pedestrians: If there are very few residences within walking distance of a destination, very few people will walk to that destination. ${ }^{117}$ By contrast, European governments have generally tolerated relatively high densities. ${ }^{118}$ If American cities deregulated density and allowed landowners to build more compact neighborhoods, American cities would likely be somewhat less automobile dependent and more like European cities. ${ }^{119}$

- American zoning codes generally mandate separation of residences from any form of commerce. ${ }^{120}$ This system of "single use zoning" 121 increases the likelihood that houses or apartments will not be within walking distance of offices

WHITMAN, supra note 5, $§ 9.18$, at 598-99 (noting that most zoning ordinances control density through minimum lot size requirements and similar regulations, which have generally been upheld by courts); Richard Briffault, Smart Growth and American Land Use Law, 21 ST. Louis U. PuB. L. REv. 253, 253 (2002) ("“[H]allmarks of American land use law [include] . . . reducing population density and dispersing residents over wider areas ....").

116. See Freilich, supra note 4, at 552 n.18 (noting that transit ridership is lower in low-density neighborhoods).

117. See Andres Duany \& Emily Talen, Making the Good Easy: The Smart Code Alternative, 29 FordHAM URB. L.J. 1445, 1447 (2002) ("[U]rban areas . . . oriented around the mobility pattern of the pedestrian . . . would be generally organized within a quarter mile radius and would contain a mix of housing types, as well as . . parks, schools, and stores.").

118. See Timothy Beatley, Green URbanism: Learning from European Cities 30, 61 (2000) (comparing the density of various European cities to the density of selected American cities and describing European suburbs as significantly more compact than American suburbs); NIVOLA, supra note 94 ("[T] of the United States is still about one-fourth that of Germany.").

119. For a detailed discussion of this proposal, see Lewyn, supra note 19, at 23-30.

120. See Briffault, supra note 115 , at 253 (stating that "the separation of different land uses from each other" is a "hallmark" of American land use law); Jerry Frug, The Geography of Community, 48 STAN. L. REV. 1047, 1091 (1996) (explaining that American zoning laws generally "mandate the separation of different areas by function"); Village of Euclid v. Ambler Realty Co., 272 U.S. 365, 391-95 (1926) (upholding the constitutionality of such zoning laws).

121. See Terry J. Tondro, Sprawl and Its Enemies: Two Cities' Efforts to Control Sprawl: An Introduction, 34 CoNN. L. REV. 511, 514 (2002) (noting "America's continued fascination with single use zoning," and defining such restrictive zoning as "the designation of separate land areas for different uses"). 
or shops. ${ }^{122}$ By contrast, European cities have been more willing to allow landowners to mix housing and commerce. ${ }^{123}$ If American cities allowed landowners to combine multifamily housing with offices and shops, Americans would have more opportunity to walk to those destinations. ${ }^{124}$

- Most American cities require landowners to provide customers with off-street parking. ${ }^{125}$ For example, Jacksonville, Florida requires many apartment complexes to provide 1.75 parking spaces per apartment, even for one bedroom apartments. ${ }^{126}$ When government forces landowners to surround their buildings with parking lots, ${ }^{127}$ pedestrians have longer and more dangerous trips to those buildings than they otherwise might - to reach a destination, a pedestrian must walk through a parking lot and dodge the vehicles traveling through that parking lot. ${ }^{128}$ Commutes through parking lots are also unpleasant because when a pedestrian has to walk through yards of parking to reach a building, the pedestrian has less to look at and feels more isolated. ${ }^{129}$ In addition, minimum parking requirements artificially reduce density - and thus reduce transit use and walkability ${ }^{130}$ - because when government forces landowners to fill their land with parking spaces, those landowners cannot use such land for housing or businesses. ${ }^{131}$ On the other hand, these regulations

122. Id. at 517 (explaining that because of the effects of single use zoning, "[v]ery few people living in America today can simply walk to the local grocer").

123. See Hall, supra note 7, at 939 (explaining that New York City's zoning code, "a model of typically American complexity," distinguishes dozens of use zones, whereas Paris's "houses, apartment buildings, shops, cafés, offices, and other commercial establishments [] fall within a single zone, General Urban"); Kushner, supra note 96, at 938 ("European cities have extensive experience with mixed use communities . ...").

124. See Lewyn, supra note 19, at 30-35 (offering a detailed discussion of this proposal)

125. See SHOUP, supra note 5, at 22, 25 (explaining that minimum parking requirements are virtually universal in the United States).

126. See JaCKSONVILLE, Fla., ORDINANCE CODE § 656.604(a)(2) (1990).

127. See supra note 5 for an explanation of why parking lots are often between streets and buildings rather than below or in back of buildings.

128. See Lewyn, supra note 19 , at 36-37.

129. See Douglas G. French, Cities Without Soul: Standards for Architectural Controls with Growth Management Objectives, 71 U. DET. MERCY L. REV. 267, 280 (1994) (noting that although parking lots in front of buildings are "inhospitable" to pedestrians, "shopfront windows provide more interesting scenery for pedestrians, and create a feeling of connection between the buildings and the public spaces bordering them").

130. See supra notes 115-19 and accompanying text explaining the relationship between density and transportation modes.

131. See SHOUP, supra note 5, at 143-44 (explaining that when Oakland, California, 
artificially subsidize drivers by creating a glut of parking, thus forcing the market price of parking downward. ${ }^{132}$ By contrast, Hamburg, Germany requires only one parking space per housing unit for owner occupied real estate, and requires even fewer for rental projects. ${ }^{133}$ If American cities deregulated parking, American neighborhoods would be more compact and thus more walkable - pedestrians would not have to waste as much time trudging through parking lots, making walking more efficient and more pleasant. ${ }^{134}$

- American local governments sometimes require the construction of streets too wide to be comfortably crossed by pedestrians. For example, in Jacksonville, the city requires that "major arterials" be at least 150 feet wide, ${ }^{135}$ which means that such streets are eight or ten lanes wide. ${ }^{136}$ Such wide

began to require one parking space per apartment, the number of apartments on a typical lot fell by $30 \%$ ).

132. Id. at 1 (" $[\mathrm{P}]$ arking is free for 99 percent of all automobile trips in the U.S."); $i d$. at 191-92 (illustrating that a driver who parks for free receives a parking subsidy of \$127-\$200 per month because landowners pass the cost of building parking lots on to consumers).

133. See James A. Kushner, Car-Free Housing Developments: Towards Sustainable Smart Growth and Urban Regeneration Through Car-Free Zoning, Car-Free Redevelopment, Pedestrian Improvement Districts, and New Urbanism, 23 UCLA J. ENVTL. L. \& POL'Y $1,14(2005)$ (noting that "[ $t$ ]he standard parking ratio in Hamburg is 0.8 spaces [per unit] in rental projects and 1.0 in owner-occupied," but sometimes the requirement is even lower).

134. See Lewyn, supra note 19, at 36-46 (offering a detailed discussion of parking and setback reform).

135. See JACKSONVILle, Fla., ORdinAnCE CODE $§ 654.113$ (1990), available at http://coj.net/City+Council/Ordinance+Code/ (setting forth regulation); id. at $\S 654.106(\mathrm{~mm})(6)$ (defining "major arterial"); see also supra note 6 (citing other examples of extremely wide streets)

136. The city's Comprehensive Plan mandates that traffic lanes be sixteen feet wide on outside lanes and twelve feet wide for other lanes. JACKSONVILLE PLANNING \& DEV. DeP'T, 2010 COMPREHENSIVE Plan: TRANSPORTATION ElEMENT 49 (2007), http://coj.net/ $\mathrm{NR} /$ rdonlyres/e6xpehk3jnkuaprdgk4lxa7gd2y4uzdqbsbukxe2zklazciusplqksvxcbl2ksetd xn5hpzb5zmb63xtj33pktc332a/COMP+PLAN-TRANS++_Revised+May+2007_\%28 new+council+names7-07\%29.pdf. Thus, a ten lane street might take up 128 feet for pavement - thirty-two feet for the two outside lanes and ninety-six feet for the eight interior lanes - allowing twenty-two feet of right-of-way for sidewalks, bicycle lanes, and landscaping. Id. at $50 \mathrm{n} .2$ ("In an urban profile, the outside lanes of major arterial . . . roadways shall include four-foot wide designated bicycle lanes."); JACKSONVILLE, Fla., ORDINANCE CODE $§ 654.133(\mathrm{~d})$ (1990), available at http://coj.net/City+Council/ Ordinance + Code/ (stating that streets serving nonresidential areas must have sidewalks five feet wide). 
streets are unpleasant for pedestrians because a wide roadway takes longer to cross than a relatively narrow street, thereby exposing the pedestrian to traffic for a longer period of time. ${ }^{137}$ Moreover, a wide street will typically have faster traffic than a relatively narrow street. ${ }^{138}$ Streets with fast moving traffic can be more dangerous for pedestrians for two reasons. First, a speeding motorist can see less than one who is driving slowly: At a speed of thirty miles per hour, a motorist has a 150 degree field of vision, but at sixty miles per hour, the motorist's field of vision is reduced by two-thirds to fifty degrees. ${ }^{139}$ Thus, a speeding motorist is less likely than a slower driver to notice pedestrians and other road users. ${ }^{140}$ Second, if a speeding motorist is involved in a collision, that collision is more likely to be fatal: A pedestrian has a $3.5 \%$ chance of being killed by a vehicle traveling at 15 miles per hour, but his or her chance of death increases to $37 \%$ when the vehicle is traveling at 31 miles per hour, and increases to $83 \%$ when the vehicle is traveling at 44 miles per hour. ${ }^{141}$ Finally, wide streets reduce population density - and thus walkability and transit use ${ }^{142}$ - by taking land for roads that private citizens could otherwise use to build housing. ${ }^{143}$

137. See Donavan v. Jones, 658 So. 2d 755, 765 (La. Ct. App. 1995) (noting that according to expert testimony, "a wider roadway takes longer to cross thus increasing the time the pedestrian is exposed to traffic").

138. See Stephen H. Burrington, Restoring the Rule of Law and Respect for Communities in Transportation, 5 N.Y.U. ENVTL. L.J. 691, 701-03 (1996) (explaining that widening roads works to speed up traffic).

139. Id. at 704 n.50.

140. Id.

141. Id. at 704; see also Philip Langdon, Calming Rural Roads: How Traffic Calming and Context-Sensitive Design Can Improve Small Towns Bisected by State Routes, Plan., May 1, 2003, at 30. Langdon states that:

In 2001, a Federal Highway Administration report indicated that lowering speed from $40 \mathrm{mph}$ to $30 \mathrm{mph}$ halves the fatality risk. In contrast, an article that appeared in 2000 on the Institute of Transportation Engineers website found that when average speed increases from $20 \mathrm{mph}$ to $30 \mathrm{mph}$, the risk of Id. at 33 . injury to pedestrians multiplies 7.6 times.

142. See supra notes $115-19$ and accompanying text discussing the link between density and transportation modes.

143. See Michele Derus, Zoning Can Curb Lower-Cost Housing: UW Study of Waukesha County Blames Wide Streets, Broad Lots, MiLwaukeE J. Sentinel, Sept. 21, 1997, at D1 (reporting that each ten feet of street width required by government regulations reduces housing supply by $3 \%$ to $4 \%$ ). 
- By contrast, European streets are often narrower than American streets. ${ }^{144}$ If American cities and suburbs would follow suit and build streets narrow enough for pedestrians to cross safely and comfortably, their streets would be more appealing to pedestrians. ${ }^{145}$

- As noted above, European governments, like American governments, have artificially dispersed population by throwing taxpayers' money at highway construction. ${ }^{146}$ If government redirected its energies towards repairing existing roads, or decided to reduce highway spending, then suburbia would become less appealing. ${ }^{147}$

In sum, American policymakers need not choose between the sprawl status quo and European levels of government regulation. Instead, Americans could create more walkable cities by reducing government regulation of density and parking, allowing landowners to build narrower, mixed-use streets, and decreasing government spending on suburban highway construction.

\section{CONCLUSION}

It is simply not the case that Europe sprawls just like America. Despite a trend towards sprawl in the late twentieth century, European cities continue to be less hostile to nondrivers than American cities and suburbs. Moreover, Europe's twentieth century trend towards sprawl appears to have moderated in the past decade or so: Major European cities are gaining population again, and public transit ridership in Europe

144. See Toni Whitt, Easy to Park, Hard to Find, Sarasota Herald-Trib., Feb. 2, 2008, at A1, available at 2008 WLNR 2062296 (referring to "narrow European streets with limited parking"); VLDB 2003, www.vldb.informatik.hu-berlin.de/shopping.html (last visited Feb. 9, 2009) (displaying two-lane commercial street in Berlin in second photo from top). Even wide European streets are more pedestrian-friendly than wide American streets. For example, the Champs-Elysees in Paris has ten lanes, but has visibly wide sidewalks and shade trees. Compare Walchli Tauber Group, Inc., http://www.wt-group.com/ stpics/Paris/Champs_Elysees.jpg (last visited Feb. 9, 2009), with Michael Lewyn, Buford Hwy-Another Bad Block for Pedestrians (Apr. 20, 2005), http://atlantaphotos.fotopic.net/ p14010301.html (suburban Atlanta street with no sidewalks at all).

145. See Lewyn, supra note 19, at 50-54 (discussing the issue in more detail and proposing street design guidelines).

146. See supra Part III.

147. See Lewyn, supra note 19 , at 55-57 (discussing the issue in more detail and proposing that suburban road construction be limited to improvements in areas already developed). 
is on the rise. It could be argued that the example of Europe is simply irrelevant to the United States because Europe's transit friendly urban form is the result of heavy-handed government regulation that would be politically impossible in the United States. But, because American government regulation has historically favored sprawl, merely eliminating pro-sprawl regulations could move urban and suburban America towards an urban form similar to Europe. Ultimately, rather than proving the inevitability of American style sprawl, the example of Europe proves the oppositethat affluent societies need not be as suburbanized and automobile dependent as the United States. 